\title{
Artisanal fishing supports breeding of malaria mosquitoes in Western Kenya
}

\author{
Wolfgang Richard Mukabana ${ }^{1,2^{*}}$, Janet Achieng Onyango ${ }^{1,2}$ and Collins Kalwale Mweresa ${ }^{2,3}$
}

\begin{abstract}
Background: Everyday hundreds of people, mainly men, set out to take part in a vibrant artisanal capture fishing (ACF) industry on Lake Victoria. It is not known whether actions of artisanal fishers, in their unrelenting quest for existence, surpass ecosystems' sustainability thresholds with potentially negative repercussions on human health with respect to malaria transmission potential. This article sought to fill this information gap.
\end{abstract}

Methods: This study used an ecosystem approach to find out how ACF processes facilitate the breeding of mosquitoes. The observational study adopted a cross-sectional design and was carried out on Mageta Island situated inside Lake Victoria in western Kenya.

Results: Of the 87 mosquito larval habitats identified 27 (31\%) were created through ACF activities. The ACF-related habitats, hereafter collectively referred to as 'fishing habitats', included fishing boats (24), trenches (1) and fish bait mines (2). About half (48\%) of Anopheles larvae were recovered from fishing habitats. The mean larval density in the fishing habitats (35.7 \pm 1.15$)$ was double that in non-fishing habitats (17.4 \pm 0.539$)$. Despite being the most common 'non-fishing habitat'type $(N=32)$, the mean number of Anopheles larvae present in rock pools (30.81 \pm 10.54$)$ was significantly less than those found inside fishing boats ( $N=24 ; 40.08 \pm 10.16)$. Overall, man-made habitats and those used to support livelihoods contained significantly more Anopheles larvae.

Conclusions: These data show that artisanal capture fishing is a key driver of malaria epidemiology on Mageta Island. This suggests that larval source management strategies in the global south should pay attention to the heterogeneity in Anopheles breeding habitats created through livelihood activities.

Keywords: Artisanal capture fishing, Mosquito larvae, Anopheles gambiae, Larval productivity, Habitat, Fishing boats, Malaria, Mageta Island, Kenya, Lake Victoria, Ecosystem health, Ecohealth

\section{Background}

Everyday hundreds of people, mainly men, depart from home to participate in a vibrant artisanal capture fishing industry in Kenya's Lake Victoria fishery [1-3]. This industry forms the primary income source for the locals $[1,4-6]$. Landed fish is hardly consumed within the fishers' households [7] due to the small stock sizes [8]. The fish is sold off to generate cash income that is used to buy food, pay for medical care and other basic needs [2, 7]. The proceeds are often supplemented with agricultural produce $[1,9,10]$. Fishing crew must increase effort to

\footnotetext{
*Correspondence: richard.mukabana@gmail.com

1 School of Biological Sciences, University of Nairobi, P.O. Box $30197-$ 00100, Nairobi, Kenya

Full list of author information is available at the end of the article
}

find, catch and obtain sizeable stocks from the declining fishery. They cope by migrating to adjacent fisheries perceived to harbor larger fish stocks $[1,11]$, migrating to fisheries near large economic markets [11, 12], using more extractive fishing gears $[1,13]$ and use of more effective fishing baits [14].

The evolving and current threat of outdoor transmitted malaria $[15,16]$, especially in outdoor groups engaging in compelling social, cultural and economic activities at night [17] e.g. capture fishers [18], can be viewed as an ecological disaster [19]. Artisanal capture fishers exert big pressure on the environment [20] through relentless exploitation of fishery resources [3, 21]. As noted elsewhere 'poor people are forced to overuse environmental resources to survive from day to day, and their 
impoverishment of the environment further impoverishes them, making their survival ever more difficult and uncertain' [22]. Persistent pressure by poverty on ecosystems also has negative repercussions on human health [19, 23-25]. Thus, artisanal capture fishing, as practiced in the Lake Victoria fishery, is not a sustainable livelihood source [1].

In this study, an ecosystem approach $[19,23-25]$ was employed to understand the association between artisanal fishing and the problem of malaria on Mageta Island in western Kenya. The central goal was to establish whether actions of artisanal fishers, in their unrelenting quest for existence, surpass ecosystems' sustainability thresholds with potentially negative repercussions on human health. This was achieved through a cross-sectional survey seeking to (a) determine if artisanal capture fishing leads to creation, hence occurrence, of Anopheles breeding habitats, and (b) establish the potential correlation between artisanal capture fishing and
Anopheles larval productivity. In the context of this study artisanal capture fishing is defined as a small-scale activity in which fish are caught in the wild using rudimentary methods. Although some authors have pointed out at the increased risk of malaria in the context of artisanal fishing $[18,26-30]$, no one has specifically assessed the link between artisanal fishing, habitat degradation and larval ecology of malaria vectors. This is the remit of this article.

\section{Methods}

\section{Study area}

This study was carried out on Mageta Island located inside Lake Victoria (Fig. 1) in Siaya County in Western Kenya. Mageta lies very close to the Kenya-Uganda border. Administratively, Mageta Island, the adjacent Magare Island and the uninhabited Sirigombe Island form Mageta Location. Mageta Location has a population of approximately 7000 persons and is adjacent to the islands of Wayasi, Siamulala, Hama, Siro and Lolwe

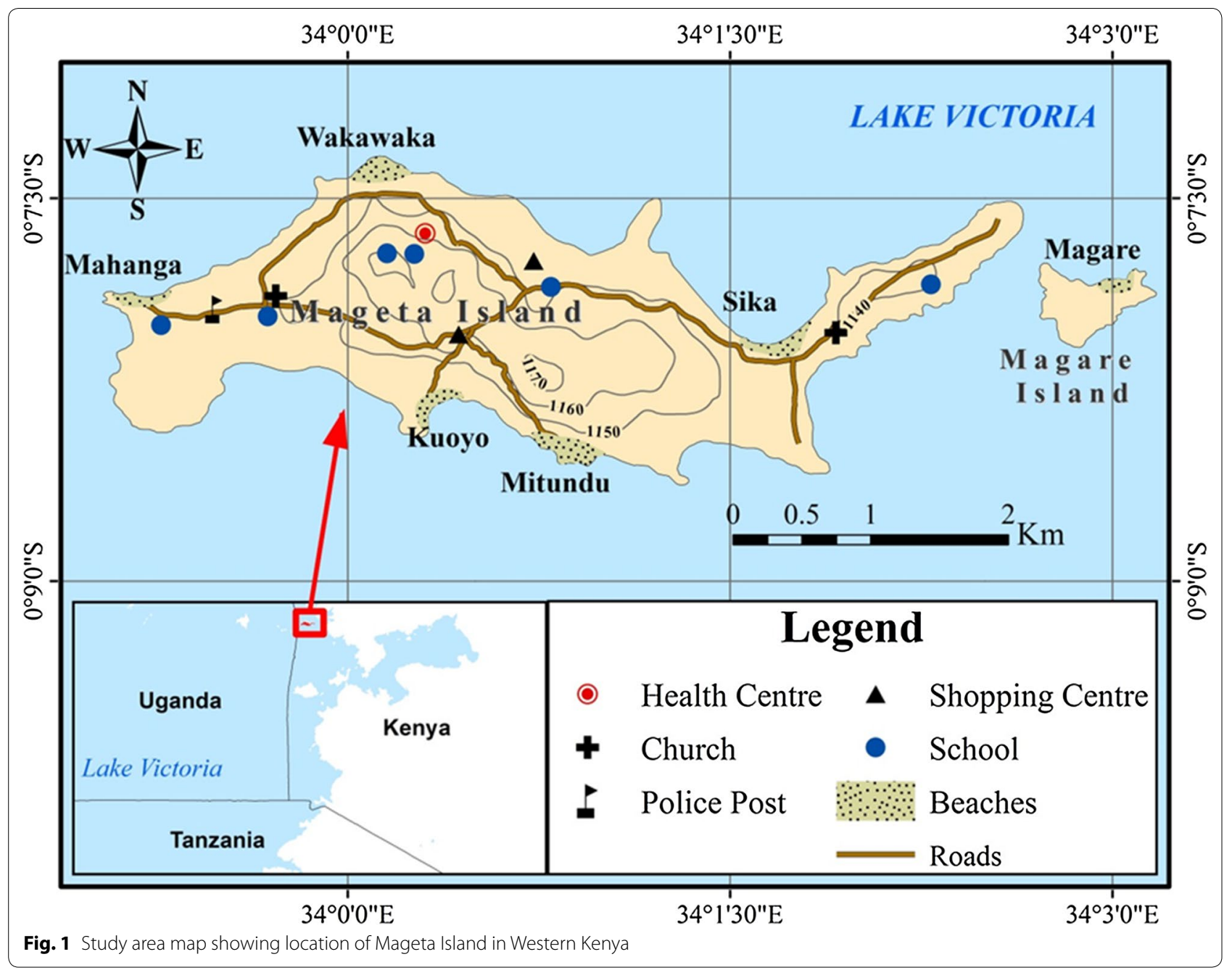


in Uganda. Mageta Island lies at an altitude of 1,140 m above sea level between $33^{\circ} 59^{\prime} 15^{\prime \prime}-34^{\circ} 2^{\prime} 30^{\prime \prime} \mathrm{E}$ and $0^{\circ}$ $7^{\prime} 15^{\prime \prime}-0^{\circ} 8^{\prime} 15^{\prime \prime} \mathrm{N}$ [31]. The surface area of the Island is approximately $7.02 \mathrm{sq} \mathrm{km} \mathrm{[32].}$

Mageta location has six fish landing beaches namely Kuoyo, Magare, Mahanga, Mitundu, Sika and Wakawaka. The main fish species caught around Mageta include the Nile tilapia (Oreochromis niloticus), the Nile perch (Lates niloticus) and the silver cyprinid (Rastrioneobola argentae). Other common fishes include species of Haplochromis, Mormyrus and Protopterus. Fresh water shrimps (Caridina nilotica) and crabs are also common. These fish and crustaceans are caught using rudimentary methods in a locally active artisanal fishing industry, which constitutes the main livelihood activity for the local inhabitants.

Animal husbandry and small scale crop farming are also practiced on Mageta Island. Domesticated animals include cattle, cats, chicken, dogs, donkeys, geese, goats, pigs and sheep [1]. Wild animals include crocodiles, lizards, monkeys, species of otter, snakes and night-grazing hippopotamuses. Lake flies, snails and many different avian species abound. Crop agriculture is concentrated mainly on the island's muddy, northern shores. The dominant crop plants include maize, beans, tomatoes and collard greens (Brassica oleracea) of the cultivar Acephala [1]. Tangerines are also present. The animals and plants most probably serve as blood and sugar meal sources for local mosquito species, respectively.

The main species of Anopheles on Mageta Island include Anopheles gambiae, Anopheles arabiensis, Anopheles funestus and Anopheles coustani [32]. Plasmodium falciparum is the main malaria parasite on the Island (pers. comm., Mageta Health Centre). Anopheles gambiae and An. funestus prefer to blood-feed on humans rather than animal hosts [33]. They also feed at night and rest indoors [33]. Unfortunately, the readily available malaria protection measures, namely long-lasting insecticidal nets, target only indoor, night-biting/resting mosquitoes. Thus, persons engaging in outdoor socioeconomic activities at night, e.g. the artisanal capture fishers of Mageta Island, remain unprotected [34]. This protection gap, together with increased resistance by malaria mosquitoes and parasites to hitherto effective insecticides and drugs [35], respectively, escalates the vulnerability of local inhabitants of Mageta Island to malaria. Innovative, locally sustainable mitigating approaches are urgently needed. In the context of this study the term Mageta Island is generally used to refer to both Mageta and Magare Islands. No work was done on Sirigombe Island.

\section{Artisanal capture fishing and creation of Anopheles larval habitats}

An observational study was performed to find out if activities associated with artisanal capture fishing facilitate creation of stagnant water bodies suitable for breeding of Anopheles larvae. Potential interaction was measured by determining the probability of finding Anopheles larvae in habitats created through artisanal capture fishing. All mosquito larval habitats on Mageta Island were identified, ecologically characterized and mapped through a cross-sectional survey. This analytical approach was effected using community health volunteers, hereafter referred to as community actors, as liaison.

The community actors helped to identify and locate stagnant water bodies where Anopheles larvae may have lived. The search focused on identifying all holes, depressions, grooves, furrows, gutters and all earthen, wooden or other containers that held stagnant water. The putative mosquito larval habitats were accessed by walking from one to the next. Guidance was provided by a different community actor [36] in each one of the 22 villages in Mageta Location. Characterization of habitats involved engaging community actors in ecological dialogue [37] that helped to succinctly describe individual habitat types. The discussions focused on how and why the habitats were created, even if inadvertently.

Habitat types created through artisanal capture fishing activities or otherwise were respectively classified as 'fishing habitats' or 'non-fishing habitats'. The outcome of finding ('Anopheles present') or not finding malaria mosquito larvae ('Anopheles absent') inside the habitats was determined and recorded. Analysis of the correlation between habitat type as a predictor of Anopheles presence in the habitats was used to fill up the research gap. Larval sampling was performed using a $350 \mathrm{ml}$ WHO dipper. Up to ten dips were taken from each larval habitat and inspected before a decision on presence (or absence) of Anopheles larvae in individual habitats was reached. Mapping of individual mosquito larval habitats was done with the aid of a GPS receiver (Garmin $\mathrm{eTrex}^{\circledR} 10$ ). The GPS data points were transferred into ArcGIS software (10.2.2) and used to develop a spot map.

\section{Artisanal capture fishing and Anopheles larval productivity}

The effect of artisanal capture fishing on Anopheles larval productivity on Mageta Island was evaluated as an integral part of the survey. Causal effects were measured by determining the statistical relationship between habitat type (i.e. 'fishing' versus 'non-fishing') and the counts of Anopheles larvae found inside individual habitats. Habitat type was further classified using bottom surface type (i.e. wooden, rocky and muddy) as a 
possible mediator of this association [38]. Three potential qualitative moderators of this relationship namely emergent plants [39], direct sunlight [38, 39] and fish predators $[40,41]$ were also assessed. Each moderator was classified into two categorical predictors of Anopheles larval productivity i.e. exposure versus nonexposure of habitats to direct sunlight, presence versus absence of emergent plants in habitats and presence versus absence of fish predators in the habitats. Beyond the presumed effect(s) of these variables Anopheles larvae were assumed to eventually emerge into adult mosquitoes through the pupal stage. These classifications of variables were superseded by diligent larval sampling.

Upon arrival at a potential mosquito larval habitat the WHO dipper was lowered gently at an angle of 45 degrees just below the water surface to allow any larvae present in the water to flow into the dipper. Sampling was done between 0900 and $1100 \mathrm{~h}$. Research team members ensured that the water was calm enough and their body shadows were not cast on the surface before a dip was taken. The number of Anopheles larvae collected from each one of the 10 dips was summed and recorded for individual habitats. Sampling was done in areas around floating debris and edges of the habitats as most preferred sites for mosquito larvae [42]. Collected larvae were identified morphologically using taxonomic keys [43]. A sub-set of mosquitoes belonging to the $A n$. gambiae complex were subjected to confirmatory DNA tests to identify them to species level [44].

\section{Data analysis}

A logistic regression model of the form "Logit (Anopheles present $)=\beta_{0}+\beta_{1}$ habitat type", where $\beta_{0}$ is the intercept of the regression line on the $y$-axis and $\beta_{1}$ is the gradient, was fitted [45] to describe the probability of finding Anopheles larvae in habitats created through artisanal capture fishing. Habitat type, classified as 'fishing habitats' or 'non-fishing habitats', was the predictor variable. Habitat content i.e. presence or absence of Anopheles larvae in the stagnant water bodies constituted the outcome variable. A P-value of 0.05 or less denoted a significant effect of artisanal capture fishing on presence of Anopheles larvae in habitats. The effect of artisanal capture fishing and habitat bottom surface type on the number of Anopheles mosquito larvae present in habitats was modelled using generalized linear models (GLM) with a Poisson distribution and a log link function [45]. The GLM models included the effects of the moderator variables on the outcome (i.e. number of Anopheles mosquitoes found in the habitats). All data were analysed using version 23 of the IBM SPSS statistical package.

\section{Results}

This study was carried out in July 2017. No rains were received during this period and the preceding 2 months. Seventy-seven out of the 100 mosquitoes subjected to molecular analysis were identified as An. gambiae sensu stricto. The rest of the mosquitoes were not identifiable, even after several repeats. No other Anopheles mosquito species were identified.

\section{Artisanal capture fishing and creation of Anopheles larval habitats \\ Habitat types}

A total of 87 mosquito larval habitats, 82 on Mageta Island and 5 on Magare Island, were identified. The habitats, classified into eight different habitat types, included rock pools $(n=32 ; 36.8 \%)$, fishing boats $(n=24 ; 27.6 \%)$, swamps $(n=11 ; 12.6 \%)$, ditches $(n=7 ; 8 \%)$, lagoons $(\mathrm{n}=7 ; 8 \%)$, fish ponds $(\mathrm{n}=3 ; 3.4 \%)$, fish bait mines $(\mathrm{n}=2$; $2.3 \%)$ and trenches $(n=1 ; 1.1 \%)$. Most of the habitat types were located on the eastern, western and southern shores of the Island, where most artisanal capture fishing activities were concentrated. Visual representations of these habitats and a spot map showing their distribution on Mageta Island are shown in Figs. 2 and 3, respectively. All fishing boats, fish bait mines and trenches were grouped together as 'fishing habitats', having been created through artisanal capture fishing activities. The 'non-fishing habitats' included all rock pools, swamps, lagoons, ditches and fish ponds. The percentages of fishing and non-fishing habitats were $31 \%(\mathrm{~N}=27)$ and $69 \%(\mathrm{~N}=60)$, respectively. Fishing boats comprised $89 \%(24 / 27)$ of the 'fishing habitats'

\section{Origin of mosquito breeding habitats}

Evolution of the habitats was largely associated with man's efforts to support livelihoods. For example, at the end of each fishing round fishers customarily fetch and pour fresh lake water in fishing boats after parking them ashore. Ditches, which are normally sunk below the water table, were created to prevent access of night-grazing hippopotamuses to food crops. The ditch water was also used to irrigate crop plants and, in one special case, a ditch was used for docking a fishing boat. The three fish ponds found on Mageta Island were used to culture edible fish. Stagnant water pools associated with fish bait mines resulted from excavation of earthworms from wet soil using bare hands or removing rocks/stones from crab traps. The earthworms and crabs are used locally as fishing baits. Most temporary housing structures used for primary fish processing were connected to dug-out trenches. The trenches often contained water originating from cleaning activities or slow-melting ice blocks present in leaky, locally-made cooler boxes used for 

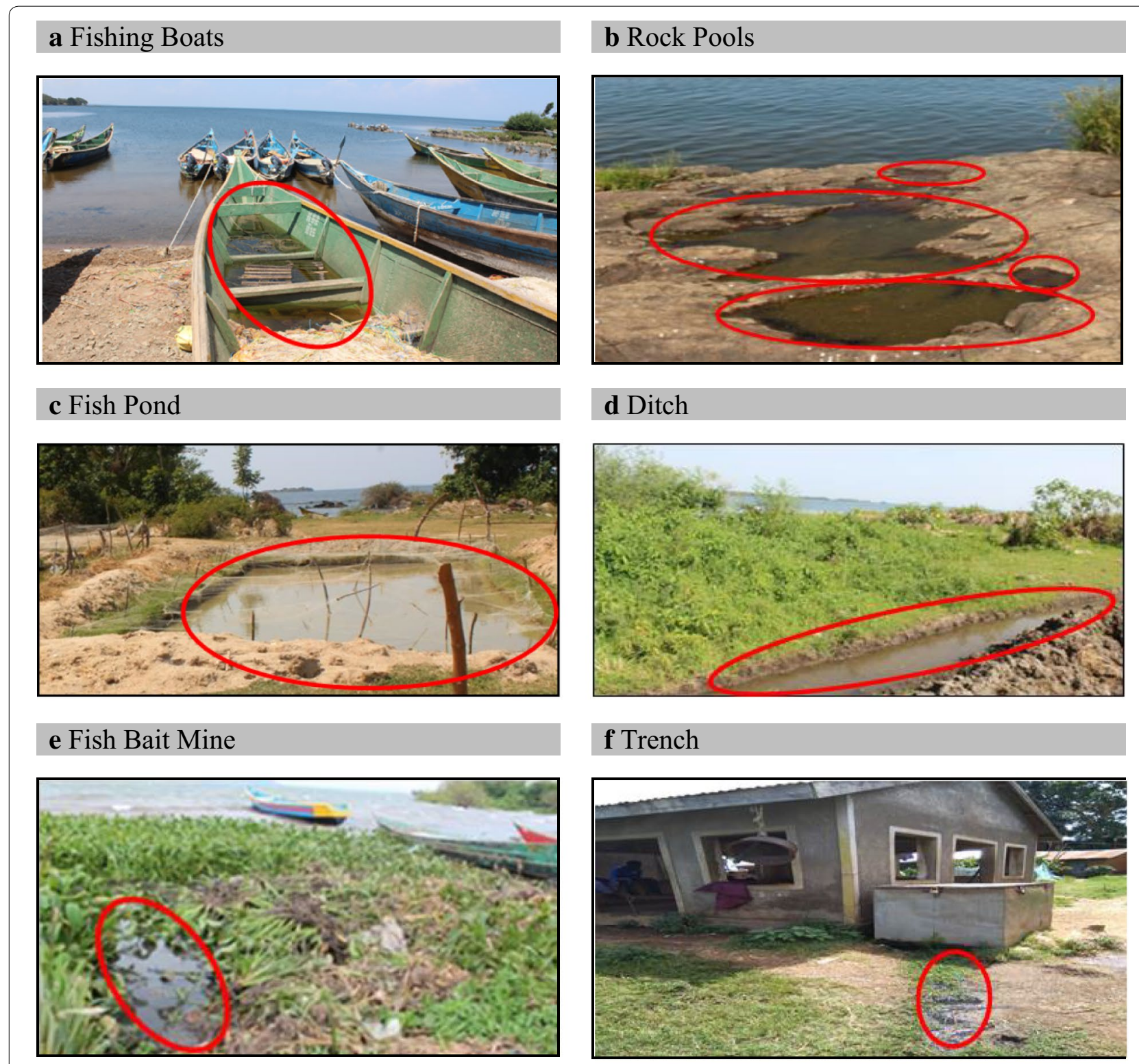

\section{g Swamp}

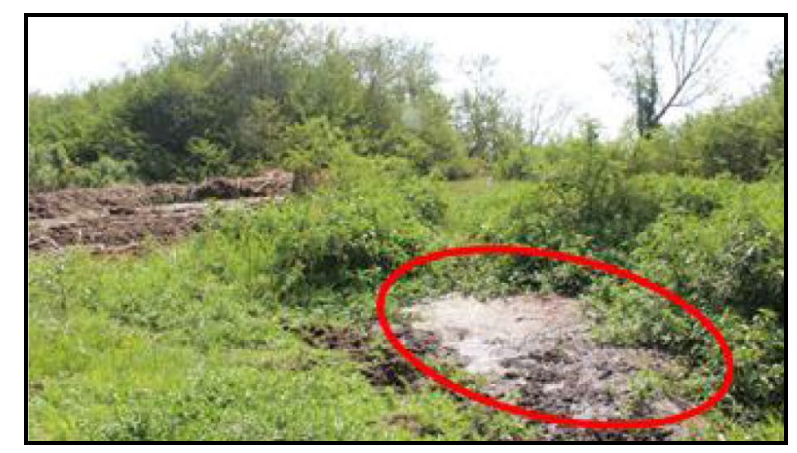

\section{h Lagoon}

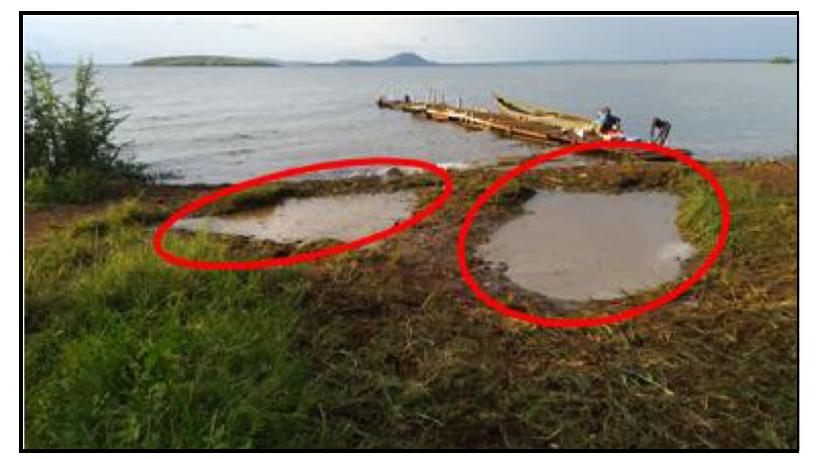

Fig. 2 Mosquito larval habitat types found on Mageta Island in Lake Victoria, Western Kenya. Areas with stagnant water are circled in red 


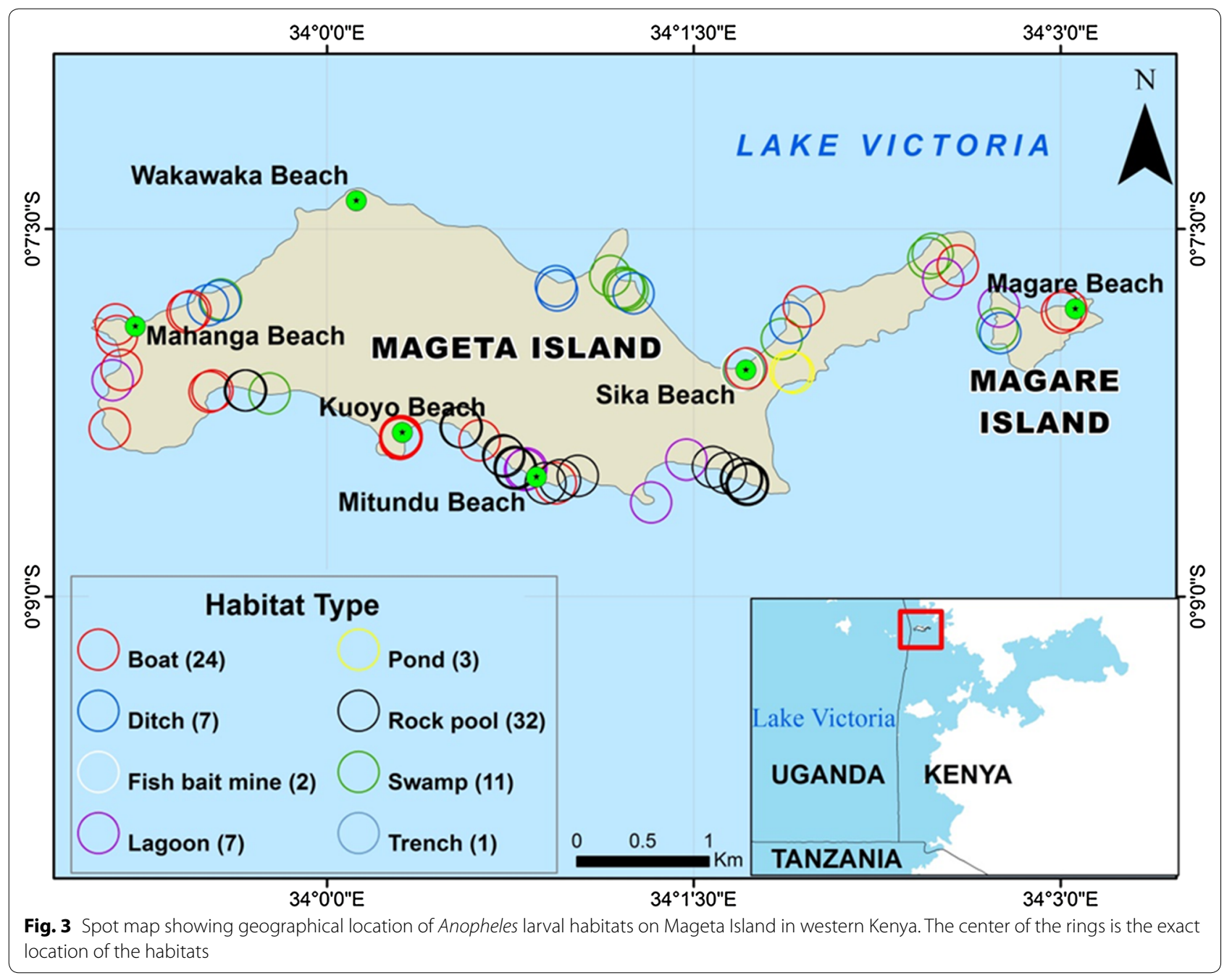

temporary storage of captured fish. The identified natural habitats were largely created through wave action on Lake Victoria. Waves deposited water near the shoreline in depressions on rocks to form rock pools, in the flat littoral zone to form swamps and behind sand bars to form lagoons [46]. In all cases adult gravid female mosquitoes laid eggs in the stagnant water bodies, which acted as larval breeding resources.

\section{Presence of Anopheles larvae in habitats}

All habitat types identified on Mageta Island with the exception of fish bait mines, fish ponds and trenches contained Anopheles larvae. No Anopheles larvae were found on Magare Island. Although one half $(50.6 \% ; 44 / 87)$ of all putative mosquito habitats contained Anopheles larvae, $74 \%$ (20/27) of 'fishing habitats' and only 38.3\% (23/60) of 'non-fishing habits' contained Anopheles larvae. Eightythree percent $(20 / 24)$ of the fishing boats contained Anopheles larvae. Fishing boats were the only 'fishing habitats' that contained Anopheles larvae. These data underscore the importance of artisanal fishing on the epidemiology of malaria on Mageta Island. The fitted logistic regression model $\left(\chi^{2}=12.11, \mathrm{df}=1, \mathrm{~N}=87, \mathrm{p}<0.001\right)$ found a significant negative association between artisanal capture fishing and the probability of finding Anopheles larvae in the habitats $(\mathrm{P}=0.001)$ (Fig. 4). The odds of finding Anopheles larvae in a habitat on Mageta Island decreased by 0.173 (95\% CI $=0.062-0.505)$ for each unit increase in the proportion of habitats associated with artisanal capture fishing.

\section{Artisanal capture fishing and Anopheles larval productivity Anopheles density in different habitat types}

The total number of Anopheles larvae collected in this study was 2008, with a mean density of $23.08 \pm 5.05$ individuals per habitat. Forty-eight percent of the larvae were recovered from fishing boats and 49\% from rock pools. Despite being the most common habitat type, the 


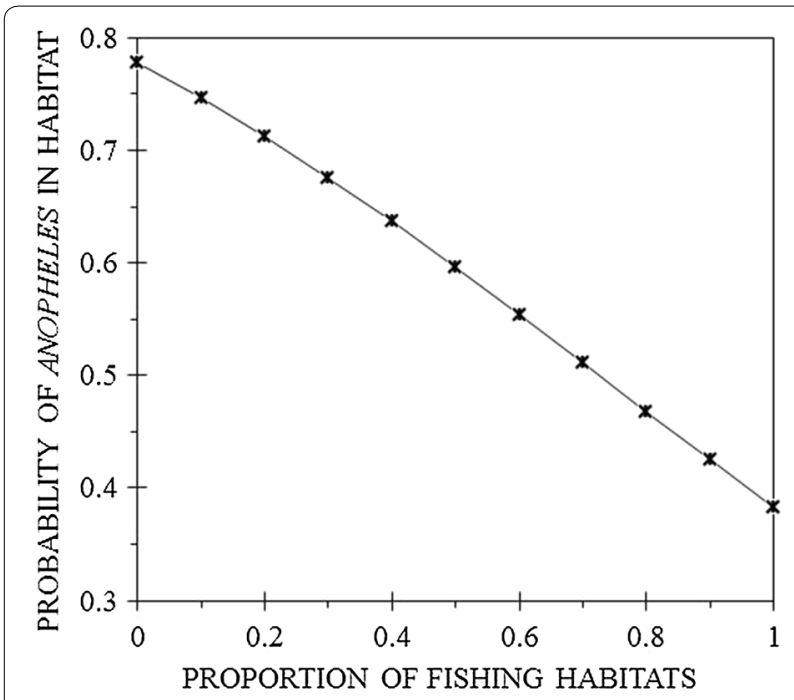

Fig. 4 Modelled probabilities of finding Anopheles mosquitoes in larval habitats associated with (artisanal capture) fishing

mean number of Anopheles larvae present in rock pools $(30.81 \pm 10.54)$ was significantly lower than those found inside fishing boats $(40.08 \pm 10.16)(\mathrm{P}=0.001)$. The mean number of Anopheles larvae in ditches, lagoons and swamps was $5.71 \pm 3.11,1.14 \pm 0.9$ and $1.09 \pm 0.7$, respectively (Fig. 5a). These data underscore the importance of fishing boats (hence artisanal capture fishing), rock pools and, to a lesser extent, ditches on the overall epidemiology of malaria on Mageta Island.

\section{Anopheles density in 'fishing' versus 'non-fishing' habitats}

About half (48\%) of malaria mosquito larvae were recovered from 'fishing habitats.' However, the mean Anopheles larval density in the 'fishing habitats' $(35.7 \pm 1.15)$ was significantly higher than that in 'non-fishing habitats' (17.4 \pm 0.539$)(\mathrm{P}=0.001)$ (Fig. 5b). This implies that there is a potential relationship between artisanal capture fishing and the density of Anopheles larvae found in habitats on Mageta Island. While no Anopheles larvae were found in fish bait mines and the trench, Anopheles eggs were observed in the fish bait mines and inside fishing boats.

\section{Anopheles density in habitats of different bottom surface types}

Inspection of bottom surfaces of identified habitats revealed that 27 had mud (3 lagoons, 11 swamps, 7 ditches, 2 fish bait mines, 1 trench and 3 fish ponds), 36 had rock (all rock pools and 4 lagoons) and 24 were wooden (all boats). The mean number of Anopheles in these habitats were $2.22 \pm 0.29,27.39 \pm 0.87$ and $40.08 \pm 1.29$, respectively (Fig. 5c). Because all fishing boats were wooden the significant association between

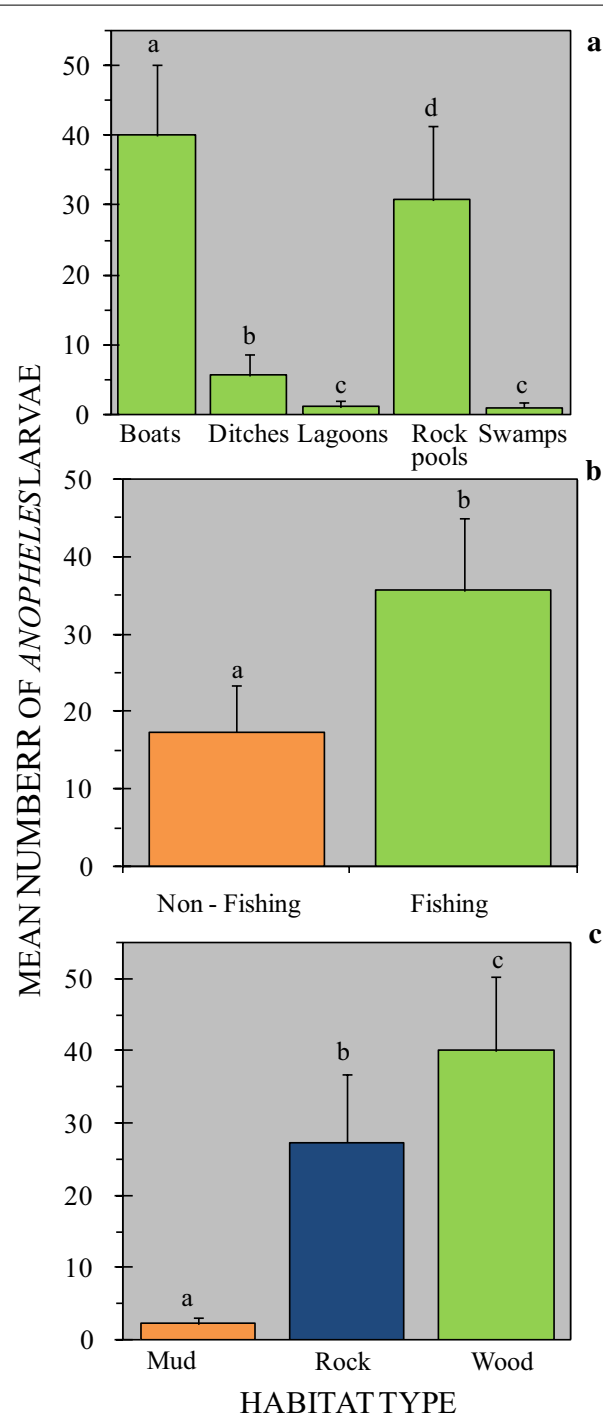

Fig. 5 Mean number of Anopheles larvae collected from different mosquito habitat types (a) on Mageta Island in western Kenya. Mean numbers of larvae collected from 'fishing' versus 'non-fishing' habitats (b) and from habitats with different surface bottom types (c) plus the standard errors of the mean values are shown. Bars with different letters (within the same panel) denote a significant difference in the mean number of mosquitoes collected. Similar letters (within the same panel) indicate no difference in the mean number of mosquitoes collected. No Anopheles larvae were recovered from fishing ponds, fish bait mines and trenches

artisanal capture fishing and Anopheles larval productivity is likely to have been driven by some evolutionarily beneficial aspect(s) of the timber used to construct the boats. Similarly, the high number of Anopheles larvae encountered in rock pools is predictive of factors associated with this habitat type that promote colonization. Pairwise comparisons revealed significant statistical differences in Anopheles density between mud versus rock 
bottomed habitats $(\mathrm{P}=0.001)$, mud versus wood bottomed habitats $(\mathrm{P}=0.001)$ and wood versus rock bottomed habitats $(\mathrm{P}=0.001)$.

\section{Effect of moderator variables on Anopheles larval productivity}

The correlation between Anopheles larval productivity and the interaction between artisanal fishing and exposure of habitats to direct sunlight could not be determined. This was also the case for the relationship between Anopheles larval productivity and the interaction between artisanal fishing and presence of emergent plants/fish predators in habitats. These potential moderator variables were all declared statistically redundant given that all fishing habitats were exposed to direct sunlight, no fishing habitats had emergent plants in them and only one fishing habitat contained fish predators. The interactions of these moderating variables with artisanal fishing are not discussed further on. However, as expected from examining the main effects, exposure to direct sunlight had a significant effect on Anopheles larval density inside habitats $[38,39](\mathrm{P}=0.001)$. More Anopheles larvae were recovered from habitats exposed to direct sunlight. Similarly, presence of emergent plants and fish predators in habitats both had significant effects on Anopheles larval density $(\mathrm{P}=0.001)$. Habitats that had emergent plants in them and those that harbored larvivorous fish had significantly fewer Anopheles larvae $(\mathrm{P}=0.001$; Table 1).

\section{Discussion}

This study applied an ecosystem approach to find out if artisanal capture fishing facilitates breeding of Anopheles larvae. Although $74 \%$ of 'fishing habitats' and only $38 \%$ of 'non-fishing habits' contained Anopheles larvae, there was a significant negative association between artisanal capture fishing and the probability of finding Anopheles larvae in the habitats. Interestingly, $83 \%$ of the fishing boats, which formed the majority of 'fishing habitats, contained Anopheles larvae. Although the total numbers of Anopheles larvae collected were about equal, the mean density in 'fishing habitats' was twice that in 'non-fishing habitats. Forty-eight percent of the larvae were recovered from fishing boats and $49 \%$ from rock pools. Despite being the most common habitat type, the mean number of Anopheles larvae present in rock pools was significantly less than those found inside the wooden fishing boats. These data underscore the importance of artisanal capture fishing on the epidemiology of malaria on Mageta Island.

The significant negative association between artisanal capture fishing and the probability of finding Anopheles larvae in habitats is puzzling on initial thought. However, this relationship is not infinite. The fitted logistic regression equation predicts that if $100 \%$ of breeding habitats on Mageta Island were to be created through artisanal capture fishing then only $38 \%$ of them would contain Anopheles larvae. On the contrary over half (78\%) of stagnant water bodies would contain Anopheles larvae if no single breeding habitat on Mageta Island was to be created through artisanal capture fishing. This analysis implies that although artisanal capture fishing is an important facet of malaria epidemiology on Mageta Island, other drivers of endemicity do exit. Thus, malaria control efforts need to be informed by holistic approaches that recognize the interdependent nature of health and other societal, developmental and ecosystem factors [25].

Peer reviewed literature about the breeding of Anopheles larvae in boats (or any wooden containers) is scarce. However, this was one of the most fascinating findings of this study. Traces of available data relate to the role of boats and other transport vessels as agents for the worldwide dispersal of arthropod vectors [47, 48]. What is more is that these data largely derive from observations on Aedes, and to a lesser extent Culex, species outside Africa [48-52]. Two recent studies document utilization of boats for breeding by Anopheles coluzzii (initially the $\mathrm{M}$ form of $A n$. gambiae sensu lato) in two fishing communities within the Wouri river estuary near the port of Duala in Cameroon [53, 54]. Data in this article corroborate these findings, albeit with respect to An. gambiae s.s., which was the only Anopheles species identified on Mageta Island. Mbida et al. [54] explain the phenomenon of $A n$. coluzzii breeding in boats, among other man-made

Table 1 Mean number ( \pm SE) of Anopheles larvae recovered from aquatic habitats that were non-exposed (predictor absent) and exposed (predictor present) to different moderating effects on Mageta Island in western Kenya

\begin{tabular}{|c|c|c|c|c|c|}
\hline \multirow[t]{2}{*}{ Predictor } & \multirow[t]{2}{*}{$\mathbf{N}$} & \multicolumn{2}{|c|}{$\begin{array}{l}\text { Mean }( \pm \text { SE) number } \\
\text { of Anopheles larvae }\end{array}$} & \multirow[t]{2}{*}{$\operatorname{Exp}(B)$} & \multirow[t]{2}{*}{$\mathbf{P}$} \\
\hline & & $\begin{array}{l}\text { Predictor } \\
\text { absent }\end{array}$ & $\begin{array}{l}\text { Predictor } \\
\text { present }\end{array}$ & & \\
\hline $\begin{array}{l}\text { Emergent } \\
\text { plants }\end{array}$ & 9 & $25.54 \pm 0.57$ & $1.87 \pm 0.48$ & 13.621 & 0.001 \\
\hline Fish predators & 22 & $30.85 \pm 0.69$ & $0.10 \pm 0.07$ & 323.885 & 0.001 \\
\hline Direct sunlight & 73 & $23.43 \pm 1.29$ & $23.32 \pm 0.57$ & 1.005 & 0.938 \\
\hline
\end{tabular}

The test statistic $\{\operatorname{Exp}(B)\}$ and the level of statistical significance between the mean numbers of larvae in exposed and non-exposed habitats are shown for each predictor. ' $\mathrm{N}$ ' refers to the number of larval habitats (out of 87 ) 'exposed' to the predictor variable. The rest of the habitats were 'not exposed' to the predictor 
habitats, as an adaptation to utilizing artificial habitats when natural ones become rare.

It is well known that An. gambiae uses manmade habitats for larval breeding $[42,55]$, but it is puzzling why fishers' boats constituted a highly profilic Anopheles larval breeding resource. This study was carried out in the dry season, thus the finding that boats formed an important breeding habitat for malaria mosquitoes is confusing. The boats should have been devoid of water at this time. By iteratively engaging community actors (most of whom were artisanal fishers) it was explained that fishers engage in an active maintenance process where fresh lake water is poured in boats parked ashore between fishing rounds. The water prevents the wood from cracking. Boats not-in-use are normally stationed ashore $[6,12]$ during months when fishing is illegal $[4$, $56,57]$, when fish catches are significantly low, when actors are off duty and during tumultuous party times when fishermen revel after receiving cash bonuses from their cooperative societies. That aside, it is unlikely that the larvae found in boats were introduced through the maintenance process. Strong waves must have killed any mosquito larvae present in lake water around the open beaches where fishing boats were parked. Besides the open lake is not a typical breeding habitat for Anopheles mosquitoes [46]. What is more is that Anopheles eggs, possibly introduced through direct oviposition by gravid females, were found inside the fishers' boats.

Perhaps the dominance of Anopheles larvae in fishers' boats can be best explained borrowing from life history theory [58-61]. A mosquito's life cycle encompasses four key life history stages namely eggs, larvae, pupae and adults [62]. Eggs, larvae and pupae are aquatic, and will most likely exist in pools of water in boats for the case of malaria vectors on Mageta Island. Utilization of boats as a breeding resource is a very risky phenomenon because this habitat type is highly ephemeral. Although water is placed in the boats in the morning hours and emptied in the late afternoon on the same day or after a few days, the most common malaria vectors in the area, i.e. An. gambiae complex mosquitoes [32], need about 1 week to complete the aquatic cycle [63]. From an evolutionary standpoint selection pressure should favor traits that promote shorter aquatic developmental periods and production of large numbers of offspring by gravid female malaria mosquitoes. Alternatively, gravid malaria vectors may, through an ecological phenomenon referred to as 'bet-hedging' [60], cope by distributing single egg loads into several fishing boats containing water. Reproduction should also entail a relatively small energy investment in each offspring [58]. This should result in a sizeable number of young offspring that are capable of evading extrinsic larval mortality [59] and developing into terrestrial adult beings. The adults should then live for long enough while accessing readily available blood meals from the vast human blood meal reservoir in the fishing hamlets.

Looking further, the larger number of Anopheles larvae in rock pools relative to mud-bottomed habitats is not surprising. This is because larvae of An. gambiae s.l. are often found in habitats containing algae [39] and rock offers a better substrate for algae to grow on than mud substrates [38]. Besides, rock pools were all found near the shoreline and the water in them was frequently refreshed by spilling waves. This served to oxygenate the water, which may have promoted Anopheles larval productivity $[64,65]$. However, the fact that most rock pools were found under tree canopies could explain the relatively lower Anopheles productivity compared to boats. Generally, anopheline larvae prefer open sun-lit waters [38, 39]. Anopheles gambiae s.l. tolerates relatively high water temperatures [65], thus the warmer sun-lit water pools in boats may have been an important factor for larval development because warm water accelerates larval development [64]. In addition, warm water temperatures in boats may have allowed more microorganisms to grow, which provided food sources for mosquito larvae [64, 66-68]. Fishing boats on Mageta Island are made using timber from the Africa teak tree (Milicia excelsa), commonly known as Mvule among locals. Unsubstantiated reports indicate that timber of this tree contains pores that harbour bacteria. These bacteria probably multiplied rapidly and acted as a mosquito larval food source [64, 66], so increasing Anopheles productivity in boats. On the contrary, presence of aged water may have harboured larger numbers of predators that suppressed abundance of Anopheles larvae [69] in some rock pools.

The majority of the Anopheles larval habitats reported in this study were created through human activities fashioned around supporting livelihoods. Artisanal capture fishing was the most notable livelihood source. This result goes in tandem with observations by other researchers in relation to crop cultivation [70, 71], livestock herding [71] and brick making [72]. The findings underscore man's own contribution towards the viciousness of malaria and affirm the link between malaria and poverty, hence the poverty trap formed by the ecology of infectious diseases $[73,74]$. This implies that the poor of the south (e.g. the artisanal fishers of Mageta Island) whose wealth, by definition, is primarily gained by extracting natural resources [19] are unable to make enough to lift themselves out of poverty [75]. They are stuck in a cycle of poverty that is almost impossible to break [73]. As fishing activities 
intensify so does the chance of increasing Anopheles larval densities in breeding habitats. This fuels malarial disease, hence the need to extract more fish to generate income as a coping strategy towards treatment.

The cross-sectional design used in this study presents several shortfalls towards associating cause to effect [76]. First, although it is generally impossible to infer the temporal sequence between exposure and outcome in crosssectional studies, it makes biological sense, in this study, to assume that the presence of water in fishing habitats (the exposure) preceded the appearance of Anopheles larvae in the water (the outcome). This is because stagnant water is a prerequisite for oviposition and larval development. Second, cross-sectional studies tend to identify a high proportion of prevalent (rather than incident) cases/ outcomes. By dialoguing with community actors it was learnt that boats containing water were parked ashore just for a few hours or days $[6,77]$. Thus, it is unlikely that most of the breeding occurring in boats resulted from boats overstaying with water. Third, although this study was conducted in an informal occupational setting, it is highly unlikely that the effect of artisanal capture fishing on creation of Anopheles larval habitats was attenuated by inherent exclusion of ramshackle fishing boats from those sampled. Boats abandoned near the shorelines because of being in conditions of disrepair also contained water received from rainfall and/or spilling waves and were included in the sample. Thus, the study suffered a limited 'healthy worker survivor effect'.

\section{Conclusions}

The data presented in this article show that artisanal capture fishing is a key driver of malaria epidemiology on Mageta Island. This underscores the need for a deeper understanding of mosquito larval ecology rather than just mapping to know if breeding habitats of Anopheles are 'few, fixed and findable', and therefore amenable to larval source management [42]. Thus, embracing an ecosystem approach to human health (ecohealth) with respect to malaria can contribute towards attainment of acceptable levels of health that will enable people to realize sustainable livelihoods [70, 78]. Larval source management strategies in the global south should be cognizant of the heterogeneity in Anopheles breeding habitats created through livelihood activities.

\section{Authors' contributions}

WRM conceived and designed the study in consultation with JAO and CKM. JAO and CKM identified the mosquitoes. WRM and JAO analyzed the data. WRM wrote the first draft of the manuscript. All authors read and approved the final manuscript.

\section{Author details}

1 School of Biological Sciences, University of Nairobi, P.O. Box 30197-00100, Nairobi, Kenya. ${ }^{2}$ Science for Health, P.O. Box 44970-00100, Nairobi, Kenya.

${ }^{3}$ School of Biological and Physical Sciences, Jaramogi Oginga Odinga University of Science and Technology, P.O. Box 210-40601, Bondo, Kenya.

\section{Acknowledgements}

All CHVs of Mageta Island are thanked for participating actively in this study. In particular Ms. Rispar Auma Otieno and Mr. Victor Onyango are thanked for taking special interest in the work that went on outside their jurisdictions. Messrs Simon Aluora and Josephat Odimo are thanked for co-coordinating and participating in field activities in Mitundu and Mahanga community (health) units, respectively. Stanley Chasia and Tim Wango are thanked for helping to draw the maps.

\section{Competing interests}

The authors declare that they have no competing interests.

\section{Availability of data and materials}

The data supporting the conclusions of this article are included within the article. The datasets used and/or analyzed during the current study are available from the corresponding author on reasonable request.

\section{Consent for publication}

Not applicable.

\section{Ethics approval and consent to participate}

This study was approved by the Scientific and Ethics Review Unit (SERU) of the Kenya Medical Research Institute (KEMRI). Protocol 560, ethical approval number KEMRI/RES/7/8/1 dated May 16, 2017.

\section{Funding}

This work was funded by the British Ecological Society (Ecologists in Africa) Grant \# EA16/1073 and the National Research Fund (NRF), Kenya. Both grants were awarded to WRM.

\section{Publisher's Note}

Springer Nature remains neutral with regard to jurisdictional claims in published maps and institutional affiliations.

Received: 3 November 2018 Accepted: 6 March 2019

Published online: 12 March 2019

\section{References}

1. Geheb K, Binns T. 'Fishing farmers' or'farming fishermen'? The quest for household income and nutritional security on the Kenyan shores of Lake Victoria. Afr Aff. 1997;96:73-93.

2. Omwega RN, Abila RO, Lwenya C. Fishing and poverty levels around Lake Victoria, Kenya. In: Odada E., Olago DO (Eds.). Proceedings of the 11th World Lakes Conference. 2006;2:193-9.

3. Kleiber D, Harris LM, Vincent ACJ. Gender and small-scale fisheries: a case for counting women and beyond. Fish Fish. 2014;16:547-62.

4. Njiru M, Kazungu J, Ngugi CC, Gichuki J, Muhoozi L. An overview of the current status of Lake Victoria fishery: opportunities, challenges and management strategies. Lakes Reserv Res Manag. 2008;13:1-12.

5. Nunan F. Understanding poverty and the environment: analytical frameworks and approaches. New York: Routledge; 2015.

6. Nathenson P, Slater S, Higdon P, Aldinger C, Ostheimer E. No sex for fish: empowering women to promote health and economic opportunity in a localized place in Kenya. Health Promot Int. 2017;32:800-7.

7. Fiorella KJ, Hickey MD, Salmen CR, Nagata JM, Mattah B, Magerenge R, et al. Fishing for food? Analyzing links between fishing livelihoods and food security around Lake Victoria, Kenya. Food Secur. 2014;6:851-60.

8. Fiorella KJ, Camlin CS, Salmen CR, Omondi R, Hickey MD, Omollo DO, et al. Transactional fish-for-sex relationships amid declining fish access in Kenya. World Dev. 2015;74:323-32. 
9. Freeman $\mathrm{HA}$, Ellis F, Allison E. Livelihoods and rural poverty reduction in Kenya. Dev. Policy Rev. 2004;22:147-71.

10. Olale $E$, Henson S. Determinants of income diversification among fishing communities in Western Kenya. Fish Res. 2012;125-6:235-42.

11. Nunan F. Mobility and fisherfolk livelihoods on Lake Victoria: implications for vulnerability and risk. Geoforum. 2010;41:776-85.

12. Nunan F. Lake ties: Fisherfolk use their social networks to navigate formal and informal rules in accessing the fisheries of Lake Victoria. SAMUDRA Report. 2018; 78

13. Fiorella KJ, Milner EM, Salmen CR, Hickey MD, Omollo DO, Odhiambo A, et al. Human health alters the sustainability of fishing practices in East Africa. Proc Natl Acad Sci USA. 2017:114:4171-6.

14. Mkumbo OC, Mlaponi E. Impact of the baited hook fishery on the recovering endemic fish species in Lake Victoria. Aquat Ecosyst Health Manag. 2007;10:458-66.

15. Durnez L, Coosemans M. Anopheles mosquitoes-new insights into malaria vectors. In: Manguin S, editor. Residual transmission of malaria: an old issue for new approaches. Chapt. 21: 2013.

16. Killeen GF. Characterizing, controlling and eliminating residual malaria transmission. Malar J. 2014:13:330.

17. Monroe A, Asamoah O, Lam Y, Koenker H, Psychas P, Lynch M, et al. Outdoor-sleeping and other night-time activities in northern Ghana: implications for residual transmission and malaria prevention. Malar J. 2015;14:35

18. Sá DR, Souza-Santos R, Escobar AL, Coimbra JCE. Malaria epidemiology in the Pakaanova (Wari) Indians, Brazilian Amazon. Bull Soc Pathol Exot. 2005:98:28-32.

19. Lebel J. Health: an ecosystem approach. Ottawa: International Development Research Centre; 2003.

20. Groeneveld J. Capture Fisheries. In: Regional State of the Coast Report: Western Indian Ocean. UNEP and WIOMSA, Nairobi, Kenya; 273-86.

21. Larsen DA, Welsh R, Mulenga A, Reid R. Widespread mosquito net fishing in the Barotse flood plain: evidence from qualitative interviews. PLoS ONE. 2018;13:e0195808.

22. World Commission on the Environment and Development. Our common future. Oxford: Oxford University Press; 1987.

23. Forget $\mathrm{G}$, Lebel J. An ecosystem approach to health. Int J Occup Environ Health. 2001;7:S1-18.

24. Charron DF. Ecohealth: origins and approach. In: Charron DF, editor. Ecohealth research in practice: innovative applications of an ecosystem approach to health. New York: Springer; 2012. p. 1-30.

25. Asakura T, Mallee H, Tomokawa S, Moji K, Kobayashi J. The ecosystem approach to health is a promising strategy in international development: lessons from Japan and Laos. Global. Health. 2015;11:3.

26. Barai D, Hyma B, Ramesh A. The scope and limitations of insecticide spraying in rural vector control programmes in the states of Karnataka and Tamil Nadu in India. Ecol Dis. 1982;1:243-55.

27. Goldberg HI, M'Bodji FG. Infant and early childhood mortality in the Sine-Saloum region of Senegal. J Biosoc Sci. 1988;20:471-84.

28. Akogbéto M. Lagoonal and coastal malaria at Cotonou: entomological findings. Santé. 2000:10:267-75.

29. Sogoba N, Doumbia S, Vounatsou P, Baber I, Keita M, Maiga M, et al. Monitoring of larval habitats and mosquito densities in the Sudan savanna of Mali: implications for malaria vector control. Am J Trop Med Hyg. 2007;77:82-8.

30. Woodburn PW, Muhangi L, Hillier S, Ndibazza J, Namujju PB, Kizza M, et al. Risk factors for helminth, malaria, and HIV infection in pregnancy in Entebbe, Uganda. PLoS NegI Trop Dis. 2009;3:e473.

31. Wamwiri FN, Nkwengulila G, Clausen PH. Hosts of Glossina fuscipes fuscipes and G. pallidipes in areas of western Kenya with endemic sleeping sickness, as determined using an egg-yolk (IgY) ELISA. Ann Trop Med Parasitol. 2007;101:225-32.

32. Ogola E, Villinger J, Mabuka D, Omondi D, Orindi B, Mutunga J, et al. Composition of Anopheles mosquitoes, their blood-meal hosts, and Plasmodium falciparum infection rates in three islands with disparate bed net coverage in Lake Victoria, Kenya. Malar J. 2017;16:360.

33. Sinka ME, Bangs MJ, Manguin S, Coetzee M, Mbogo CM, Hemingway $\mathrm{J}$, et al. The dominant Anopheles vectors of human malaria in Africa, Europe and the Middle East: occurrence data, distribution maps and bionomic précis. Parasit Vectors. 2010;3:117.
34. Olanga EA, Okombo L, Irungu LW, Mukabana WR. Malaria parasites and vectors on Rusinga Island, western Kenya. Parasit Vectors. 2015;8:250.

35. Bhattarai A, Ali AS, Kachur SP, Martensson A, Abbas AK, Khatib R, et al. Impact of artemisinin-based combination therapy and insecticidetreated nets on malaria burden in Zanzibar. PLoS Med. 2007:4:e309.

36. Kaseje DC, Spencer HC, Sempebwa EK. Characteristics and functions of community health workers in Saradidi, Kenya. Ann Trop Med Parasitol. 1987:81(1):56-66.

37. Smith PG, Morrow RH. Methods for field trials of interventions against tropical diseases: a 'Toolbox'. Oxford: Oxford University Press; 1991.

38. Minakawa N, Mutero CM, Githure Jl, Beier JC, Yan G. Spatial distribution and habitat characterization of anopheline mosquito larvae in Western Kenya. Am J Trop Med Hyg. 1999;61:1010-6.

39. Gimnig JE, Ombok M, Kamau L, Hawley WA. Characteristics of larval Anopheline (Diptera: Culicidae) habitats in Western Kenya. J Med Entomol. 2001;38:282-8.

40. Walshe DP, Garner P, Adeel AA, Pyke GH, Burkot TR. Larvivorous fish for preventing malaria transmission. Cochrane Database Syst Rev. 2017;12:CD008090.

41. Gachelin G, Garner P, Ferroni E, Verhave JP, Opinel A. Evidence and strategies for malaria prevention and control: a historical analysis. Malar J. 2018;17:96

42. WHO. Larval source management-a supplementary measure for malaria vector control: an Operational Manual. Geneva: World Health Organization; 2013.

43. Gillies MT, Coetzee M. A supplement to the Anophelinae of Africa South of the Sahara (Afrotropical Region). Publications of the South African Institute for Medical Research. 1987;55:1-43.

44. Scott JA, Brogdon WG, Collins FH. Identification of single specimens of the Anopheles gambiae complex by the polymerase chain reaction. Am J Trop Med Hyg. 1993:49:520-9.

45. Field A. Discovering statistics using SPSS. 3rd ed. London: Sage Publications; 2011

46. Minakawa N, Dida GO, Sonye GO, Futami K, Njenga SM. Malaria vectors in Lake Victoria and adjacent habitats in Western Kenya. PLoS ONE. 2012:7:e32725.

47. Mouchet J, Giacomini T, Julvez J. Human diffusion of arthropod disease vectors throughout the world. Santé. 1995;5:293-8.

48. Guagliardo SA, Morrison AC, Barboza JL, Requena E, Astete H, VazquezProkopec $\mathrm{G}$, et al. River boats contribute to the regional spread of the dengue vector Aedes aegypti in the Peruvian Amazon. PLoS Negl Trop Dis. 2015:9:e0003648.

49. Pratt JJ Jr, Hexerick RH, Harrison JB, Haber L. Tires as a factor in the transportation of mosquitoes by ships. Milit Surg. 1946:99:785-8.

50. Belton P, Belton OC. Aedes togoi comes aboard. J Am Mosq Control Assoc. 1990:6:328-9.

51. Tsunoda T, Fukuchi A, Nanbara S, Higa Y, Takagi M. Aedes mosquito larvae collected from Ishigaki-jima and Taketomi-jima Islands in southern Japan. Southeast Asian JTrop Med Public Health. 2012:43:1375-9.

52. Guagliardo SA, Morrison AC, Luis BJ, Wesson DM, Ponnusamy L, Astete H, et al. Evidence for Aedes aegypti (Diptera: Culicidae) oviposition on boats in the Peruvian Amazon. J Med Entomol. 2015;52:726-9.

53. Etang J, Mbida MA, Ntonga AP, Binyang J, Eboumbou MCE, Lehman LG, et al. Anopheles coluzzii larval habitat and insecticide resistance in the island area of Manoka, Cameroon. BMC Infect Dis. 2016;16:217.

54. Mbida MA, Etang J, Ntonga AP, Moukoko EC, Awono-Ambene P, Tagne D, et al. New insight into Anopheles coluzzii Coetzee \& Wilkerson, 2013 larval ecology in the Wouri estuary, Littoral-Cameroon. Bull Soc Pathol Exot. 2017;110:92-101 (in French)

55. Fillinger $\mathrm{U}$, Lindsay $\mathrm{SW}$. Larval source management for malaria control in Africa: myths and reality. Malar J. 2011;10:353.

56. Ntiba MJ, Kudoja WM, Mukasa CT. Management issues in the Lake Victoria watershed. Lakes Reserv Res Manag. 2001;6:211-6.

57. Njiru M, Getabu A, Othina A, Wakwabi E. Are the management measures successful in Lake Victoria, Kenya? The case of Nile perch and Nile tilapia fishery. Afr J Ecol. 2007:45:315.

58. Stearns SC. The evolution of life histories. Oxford: Oxford University Press; 1992.

59. Reznick D, Bryant MJ, Bashey F. r-and K-selection revisited: the role of population regulation in life-history evolution. Ecology. 2002;83:1509-20. 
60. Begon M, Townsend CR, Harper JL. Ecology: from individuals to ecosystems. 4th ed. Oxford: Blackwell Publishing; 2006.

61. Dobson FS. A lifestyle view of life-history evolution. Proc Natl Acad Sci USA. 2007:4:17565-6.

62. Clements AN. The biology of mosquitoes. In: Development, nutrition and reproduction. vol. 1, CABI Publishing, Wallingford, UK; 1999.

63. Mamai W, Lees RS, Maiga H, Gilles JR. Reusing larval rearing water and its effect on development and quality of Anopheles arabiensis mosquitoes. Malar J. 2016:15:169.

64. Kipyab PC, Khaemba BM, Mwangangi JM, Mbogo CM. The physicochemical and environmental factors affecting the distribution of Anopheles merus along the Kenyan coast. Parasit Vectors. 2015;8:221.

65. Dida GO, Anyona DN, Abuom PO, Akoko D, Adoka SO, Matano AS, et al. Spatial distribution and habitat characterization of mosquito species during the dry season along the Mara River and its tributaries, in Kenya and Tanzania. Infect Dis Poverty. 2018;7:2

66. Kaufman MG, Walker ED, Smith TW, Merritt RW, Klug MJ. Effects of larval mosquitoes (Aedes triseriatus) and stem flow on microbial community dynamics in container habitats. Appl Environ Microbiol. 1999;65:2661-73.

67. Kaufman MG, Wanja E, Maknojia S, Bayoh MN, Vulule JM, Walker ED. Importance of algal biomass to growth and development of Anopheles gambiae larvae. J Med Entomol. 2006;43:669-76.

68. Ponnusamy L, Xu N, Stav G, Wesson DM, Schal C, Apperson CS. Diversity of bacterial communities in container habitats of mosquitoes. Microb Ecol. 2008;56:593-603.

69. Munga S, Vulule J, Kweka EJ. Response of Anopheles gambiae s.l. (Diptera: Culicidae) to larval habitat age in western Kenya highlands. Parasit Vectors. 2013;6:13.
70. Dunn CE, Makungu C, Le Mare A. Malaria risk behaviours, socio-cultural practices and rural livelihoods in Southern Tanzania: implication for bednet usage. Soc Sci Med. 2011;72:408-17.

71. Shayo EH, Rumisha SF, Mlozi MR, Bwana VM, Mayala BK, Malima RC, et al. Social determinants of malaria and health care seeking patterns among rice farming and pastoral communities in Kilosa District in central Tanzania. Acta Trop. 2015;144:41-9.

72. Carlson JC, Byrd BD, Omlin FX. Field assessments in western Kenya link malaria vectors to environmentally disturbed habitats during the dry season. BMC Pub Health. 2004;4:33.

73. Bonds MH, Keenan DC, Rohani P, Sachs JD. Poverty trap formed by the ecology of infectious diseases. Proc Biol Sci. 2010;277:1185-92.

74. Berthélemy JJ, Thuilliez OD, Gaudart J. Malaria and protective behaviours: is there a malaria trap? Malar J. 2013:12:200.

75. Cinner JE, Daw T, McClanahan TR. Socioeconomic factors that affect artisanal fishers' readiness to exit a declining fishery. Conserv Biol. 2009;23:124-30.

76. Aschengrau A, Seage GR III. Essentials of epidemiology in public health Burlington: Jones \& Bartlett Learning; 2013.

77. Camlin CS, Kwena ZA, Dworkin SL. Jaboya vs. jakambi: status, negotiation, and HIV risks among female migrants in the'sex for fish' economy in Nyanza Province, Kenya. AIDS Educ Prev. 2013;25:216-31.

78. Le Mare A, Makungu C, Dunn C. "Yes we are here, living, but malaria is surrounding us": sustainable livelihoods and malaria in Tanzania. Dev Pract. 2014;24:216-33.
Ready to submit your research? Choose BMC and benefit from:

- fast, convenient online submission

- thorough peer review by experienced researchers in your field

- rapid publication on acceptance

- support for research data, including large and complex data types

- gold Open Access which fosters wider collaboration and increased citations

- maximum visibility for your research: over 100M website views per year

At BMC, research is always in progress.

Learn more biomedcentral.com/submissions 